\title{
Effect of Chemical Nitrogen Fertilizers under Organic and Bio-Fertilization on Fruit and Oil Yields of Fennel (Foeniculum Vulgare Mill.)
}

\author{
Ibrahim A. Youssef ${ }^{1}$; Mohamed E. Ali ${ }^{1}$; Esmat H.A. Noufal ${ }^{1}$; Safwat A. Ismail ${ }^{2}$; Maha Ali ${ }^{1^{*}}$ \\ ${ }^{1}$ Department of Soil and Water, Fac. of Agric, Benha Univ. \\ ${ }^{2}$ Soil, Water and Environment Res. Inst., A.R.C.
}

Received: $12 / 4 / 2020$

\begin{abstract}
Two Field experiments were carried out in a newly reclaimed soil at a private farm of Village No 8 in ElMinia Governorate, Egypt during the two successive seasons of 2016/2017 and 2017/2018 to evaluate the effect of two chemical nitrogen fertilizers (urea and ammonium sulphate) with and without organic and bio-fertilization on fruit and oil yields of fennel plant. The experiment was performed in split- split plot design. Organic treatments $(0.0$ and $5.0 \mathrm{t}$ compost $\left.\mathrm{fed}^{-1}\right)$ were arranged in main plots, chemical nitrogen treatments $\left(0.0,10.0,50.0\right.$ and $\left.80.0 \mathrm{~kg} \mathrm{~N}^{-1} \mathrm{~d}^{-1}\right)$ as urea or ammonium sulphate were allocated in sub plots and bio-fertilizer (without and with) were applied in sub-sub plots. The results showed that herb, fruit and essential oil yields of fennel were significantly improved by increasing N- level of both chemical fertilizers and also by addition of compost and biofertilizer. The results of the interaction among

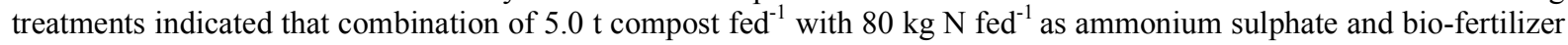
gave the highest values of herb, fruit and oil yields of fennel.
\end{abstract}

Keywords: Fennel plant, mineral fertilizers, compost and bio-fertilizer, herb/fruit/oil yields

\section{INTRODUCTION}

Fennel (Foeniculum vulgare Mill.) is one of the most important medicinal plants grown in Egypt. It is a winter annual herb belonging to the family Apiaceae. It is mainly growing in the Middle Egypt, like El-Minia and Assuit. This plant has branching stem with 1-2 meter high, its leaves are 3-4 pinnately compound, its ambles are yellow with small 5-petaled flowers, and its fruits are oval 4-10 mm long with strong sweet taste and smell. Fennel fruits contain about $2.5 \%$ essential oil and fenchone $(20 \%)$ is the most important components. It is used in the medicine as a stimulant, diuretic, carminative, sedative, galactagogic, emmenagogic, expectorant and antispasmodic. Also, it is used to treat some diseases like cholera bile disturbances, nervous disorder, constipation, dysentery, diarrhea as well as control of diseases affecting chest, lung, spleen, kidneys and in colic pains (Chiej, 1984; Charles et al., 1993). In addition, fennel fruits are used in preparation of various dishes such as soups, sauces, pastries, confectioneries, pickles and meat dishes. In some countries leaf stakes and tender shoots are used as salads.

The technical improvement of fertilization has a major contributing in increasing crops production. Different sources of chemical nitrogen fertilizers, such as urea $(46.5 \% \mathrm{~N})$, ammonium nitrate $(33.5 \% \mathrm{~N})$ and ammonium sulphate $(20.5 \%)$ are usually used in the Egyptian agriculture. The influence of nitrogen fertilizers is mainly due to their effects on the soil reaction $(\mathrm{pH})$ and nutrients availability. Some fertilizer materials leave an acidic or basic residue in the soil and others have no influence on soil reaction (Tisdale and Nelson, 1975). Mineral nutrients, especially nitrogen are very important for plants due to its role in structure of several components in the plants, e.g. protein, hormones, amino acids, enzymes and nucleic acids. The newly reclaimed Egyptian soils of Egypt are poor in their nitrogen contents, therefore application of suitable amounts and sources of nitrogen is considered to be an important factor for plant growth. The application of

Corresponding author e-mail: maha.ali@fagr.bu.edu.eg nitrogen increased seed yields as well as oil content of fennel plants (El-Wahab and Mohamed, 2007). Organic fertilizers, especially compost have been intensively used at the last decades. Application of organic fertilizers have many advances led to marked increases in the nutrient uptake and in soil biological, chemical and physical properties. Also, they can adjust the release of nutrients, encourage the growth of plant roots, beneficial microorganisms and earthworms, and help in the suppression of certain plant diseases, soil borne diseases and parasites (Ayyat, 2017).

Bio-fertilizers have different roles than mineral and organic fertilizers, where they do not directly supply any nutrients to plants. Its production is relatively simple and cheap in comparison to both chemical and organic fertilizers. Using bio-fertilizers, which contain many microbial strains can lead to marked decreases for the use of mineral fertilizers, and then get high quality products without harmful for human health. The use of soil microorganisms can fix the atmospheric nitrogen and increase the availability of soil nutrients, the decomposition of plant materials and the forming of humic acid in the soils. Application of bio-fertilizers decreases the use of chemical fertilizers and considers an effective tool for the soil management with less environmental pollution. Also, bio-fertilizers can decrease the production costs, and increase the crop yields due to supplying the soils with available nutrients and growth promoting substances (Metin et al., 2010).

Therefore, the aim of this study was to investigate the integrated effect of chemical nitrogen fertilizer sources and levels with and without an organic manure and bio-fertilizer on herb and fruit yields as well as essential oil percentage and yield of fennel plants grown in a newly reclaimed soil.

\section{MATERIALS AND METHODS}

Two field experiments were conducted in a newly reclaimed soil at a private farm in Village No. 8 at El-Minia Governorate, Egypt during the two 
successive seasons of 2016/2017 and 2017/2018 to evaluate the effect of chemical nitrogen sources at different levels with and without compost and bio fertilization on herb and fruit yields as well as essential oil percentage and yield of fennel plants.

Seeds of fennel plants were received from the Medical and Aromatic Plant Section, Agricultural Research Center (ARC), Egypt. The experimental plot was $3 \times 3.5 \mathrm{~m}(10.5 \mathrm{~m} 2$ which equal $1 / 400 \mathrm{fed})$. The fennel seeds were sown in 22 and 27 October for the two seasons, respectively. The plants were thinned to two plants/ hill after 30 days from sowing. Phosphors fertilizer as superphosphate $\left(15.5 \% \mathrm{P}_{2} \mathrm{O}_{5}\right)$ at a rate of $300 \mathrm{~kg}$ superphosphate fed $^{-1}$ before planting during land preparation, while potassium fertilizer as potassium sulphate $\left(48 \% \mathrm{~K}_{2} \mathrm{O}\right)$ at a rate of $50 \mathrm{~kg}$ potassium sulfate fed $^{-1}$ was added in two equal doses, the first after one month from the planting and the second after one month later. All recommended agricultural practices for fennel were done as Ministry of Agric.

A surface soil sample $(0-30 \mathrm{~cm})$ was taken from the experimental site in the two seasons before sowing to determine some soil physical properties according to Klute (1986) and soil chemical properties according to AOAC (1985). Physical and chemical properties of the studied soil were presented in Table (1).

Some properties of the used compost (received from El-Neel for Solid Waste Utilization, New Minia City) were determined according to AOAC (1985) and listed in Table (2).

Table (1): Some physical and chemical properties of the experimental soil

\begin{tabular}{|c|c|c|}
\hline Properties & $1^{\text {st }}$ season & $2^{\text {nd }}$ season \\
\hline Sand \% & 88.30 & 86.80 \\
\hline Silt $\%$ & 7.50 & 7.40 \\
\hline Clay \% & 4.20 & 5.80 \\
\hline Texture grade & Sand & Sand \\
\hline pH (in 1:2.5 water sustention ) & 8.10 & 8.14 \\
\hline $\mathrm{EC} \mathrm{dS} \mathrm{m}^{-1}$ (in 1:5 soil water extraction) & 1.73 & 1.96 \\
\hline Soil organic matter $\left(\mathrm{g} \mathrm{kg}^{-1}\right)$ & 1.1 & 1.3 \\
\hline $\mathrm{CaCO}_{3}\left(\mathrm{~g} \mathrm{~kg}^{-1}\right)$ & 51.2 & 43.7 \\
\hline \multicolumn{3}{|c|}{ Soluble cations $\mathrm{C} \operatorname{mol}_{\mathrm{e}} \mathrm{L}^{-1}$} \\
\hline $\mathrm{Ca}^{2+}$ & 10.40 & 11.60 \\
\hline $\mathbf{M g}^{2+}$ & 5.80 & 6.20 \\
\hline $\mathrm{Na}^{+}$ & 0.78 & 1.14 \\
\hline $\mathbf{K}^{+}$ & 0.04 & 0.17 \\
\hline \multicolumn{3}{|c|}{ Soluble anions $C \operatorname{mol}_{e} \mathbf{L}^{-1}$} \\
\hline $\mathrm{CO}_{3}{ }^{2-}$ & $\overline{--}$ & -- \\
\hline $\mathrm{HCO}_{3}^{-}$ & 2.00 & 3.33 \\
\hline $\mathrm{Cl}^{-}$ & 9.82 & 10.01 \\
\hline $\mathrm{SO}_{4}{ }^{2-}$ & 5.20 & 5.77 \\
\hline Soil available N (mg kg$\left.{ }^{-1}\right)$ & 2.21 & 2.63 \\
\hline Soil available $P\left(\mathrm{mg} \mathrm{kg}^{-1}\right)$ & 5.20 & 6.17 \\
\hline Soil available $K\left(\mathrm{mg} \mathrm{kg}^{-1}\right)$ & 32.18 & 33.35 \\
\hline
\end{tabular}

Table (2): Some properties of the used compost

\begin{tabular}{lcc}
\hline Properties & First season & Second season \\
\hline Bulk density $\left(\mathbf{K g ~ m}^{-\mathbf{3}}\right)$ & 650 & 680 \\
Moisture (\%) & 27 & 26 \\
pH (in 1:10 compost-water suspension) & 7.80 & 7.60 \\
EC $\left(\mathbf{d S m} \mathbf{- 1}^{-1}\right.$ in 1:10 compost- water extract) & 2.20 & 2.50 \\
Organic matter $\left(\mathbf{g ~ k g}^{-1}\right)$ & 330 & 340 \\
Organic carbon $\left(\mathbf{g ~ k g}^{-1}\right)$ & 192 & 197 \\
Total N $\left(\mathbf{g ~ k g}^{-1}\right)$ & 12 & 11 \\
Total P $\left(\mathbf{g ~ k g}^{-1}\right)$ & 6.50 & 7.00 \\
Total K $\left(\mathbf{g ~ k g}^{-1}\right)$ & 10 & 12 \\
C/N ratio & $16: 1$ & $18: 1$ \\
\hline
\end{tabular}


A split-split plot design in four replicates was performed. The compost treatments (without and with 5 $\mathrm{t}$ compost $\left.\mathrm{fed}^{-1}\right)[\mathrm{A}]$ were applied in main plots, chemical nitrogen sources and their levels $[\mathrm{B}]$ were arranged in sub-plots and the sub-subplots were occupied with bio-fertilizer (without and with biofertilizer) $[\mathrm{C}]$.

\section{Chemical nitrogen sources and levels were:}

- Without nitrogen fertilization

- $10 \mathrm{~kg} \mathrm{~N}$ fed $^{-1}$ as urea $(46.5 \% \mathrm{~N})$.

$-10 \mathrm{~kg} \mathrm{~N} \mathrm{fed}^{-1}$ as ammonium sulphate (AS, $20.5 \% \mathrm{~N}$ ).

$-50 \mathrm{~kg} \mathrm{~N} \mathrm{fed}^{-1}$ as urea $(46.5 \% \mathrm{~N})$.

$-50 \mathrm{~kg} \mathrm{~N} \mathrm{fed}^{-1}$ as $\mathrm{AS}(20.5 \% \mathrm{~N})$.

$-80 \mathrm{~kg} \mathrm{~N} \mathrm{fed}^{-1}$ as urea $(46.5 \% \mathrm{~N})$.

$-80 \mathrm{~kg} \mathrm{~N} \mathrm{fed}^{-1}$ as $\mathrm{AS}(20.5 \% \mathrm{~N})$.

The nitrogen treatments were added in four equal doses, the first after one month from thinning and then after every 20 days. Compost was added before planting and during the soil preparation. The commercial biofertilizer, namely, Azotobacterin (mainly contained the N2-fixing Azotobacter) was provided by Department of Microbiology Soil, Water and Environment Institute, ARC. The bio-fertilizer was applied twice to soil beside the plants at a rate of $5 \mathrm{ml} \mathrm{plant}^{-1}$, the first dose was added after 45 days from thinning, while the second one was applied after one month from the first one. The plants were immediately irrigated after application of the bio-fertilizer.

\section{Data recorded}

The plants were harvested in mid of April for the two seasons. Five plants were randomly taken from each plot to measure the following parameters.

Yield parameters: herb and fruit yields were determined as $\mathrm{kg} \mathrm{fed}^{-1}$

Oil parameters: Essential oil (\%) in fruits was determined and converted to oil yield $\left(\mathrm{L} \mathrm{fed}^{-1}\right)$. Essential oil yield $\mathrm{L} \mathrm{fed}^{-1}$. $=$ Essential oil $\% \mathrm{x}$ dry weight of fruit yield

\section{Statistical analysis:}

Data were statistically analyzed by least significant differences according to Snedecor and Cochran (1980). Differences among treatments were compared using the least significant difference test at $\mathrm{P}<0.05$.

\section{RESULTS}

\section{Yield parameters}

The response of yield parameters (herb and fruit yields) to the applied compost, chemical nitrogen fertilizers and bio-fertilizer are given in Tables ( 3 and 4). Concerning the main effect of compost, the results clearly showed that addition of $5 \mathrm{t}$ compost $\mathrm{fed}^{-1}$ significantly increased herb and fruit yields of fennel in both seasons.
Concerning the main effect of chemical nitrogen fertilization, the data revealed that increasing the rate of the applied nitrogen in both forms (mineral and organic) significantly increased both herb and fruit yields. Moreover, ammonium sulphate fertilizer was more effective on fennel yield than urea. Accordingly, in the absence of bio-fertilizer application, the greatest herb and fruit yields (1445 and $1021 \mathrm{~kg} \mathrm{fed}^{-1}$ in the first season, and 1481 and $1129 \mathrm{~kg} \mathrm{fed}^{-1}$ in the second one, respectively) were recorded under $80 \mathrm{Kg} \mathrm{N}^{-1}$ as ammonium sulphate. These values under the application of bio-fertilizer were 1470 and 1106 in the first season, and 1512 and 1220 in the second season for herb and fruit yields, respectively.

As for the bio-fertilization, the obtained data indicated that bio-fertilizer application had a considerable effect on herb and fruit yields of fennel. The relative increases of herb and dry yields caused by bio-fertilization reached 4.2 and $21.5 \%$ in the first season, while the corresponding increases in the second season were 3.2 and $14.2 \%$ as compared with the no bio-fertilizer treatment.

Considering the interaction effect of the studied treatments, the results clearly showed that both herb and fruit yields were significantly affected only by the threeway interaction among the three studied factors. Fertilizing fennel plants with $50 \mathrm{~kg} \mathrm{~N}$ per feddan as urea or ammonium sulphate in combination with $5 \mathrm{t}$ compost fed $^{-1}$ and bio-fertilizer gave herb, fruit and oil yields equal statistically to their corresponding values under the treatment $80 \mathrm{~kg} \mathrm{~N}$ fed $^{-1}+$ compost + biofertilizer. In general, the highest fennel yields were obtained for plants received $80 \mathrm{Kg} \mathrm{N}^{-1} \mathrm{~d}^{-1}$ as ammonium sulphate in the presence of compost and bio-fertilizer. On the other hand, the untreated plants (control) exhibited the lowest values of herb and fruit yields.

\section{Essential oil yield}

The data presented in Tables (5 and 6) showed the effect of compost, nitrogen- and bio-fertilizers on essential oil yield. This parameter was increased due to treating fennel plants with compost, chemical $\mathrm{N}$ and bio-fertilizers. The increment in oil yield caused by compost application reached $49.5 \%$ higher than no compost application in the first season at a rate of $5 \mathrm{t}$ $\mathrm{fed}^{-1}$. The corresponding increase in the second season was $58.5 \%$. Concerning the effect of applied nitrogen, the results showed that the oil yield values gradually increased as nitrogen level increased under the form of urea or ammonium sulphate and the ammonium sulphate gave higher oil yield than urea. With respect to bio-fertilizer, the data indicated that bio-fertilization increased oil yield by about $22.25 \%$ in the first season, and the same trend was obtained in the second season. Regarding the interaction effect, it is evident that the interaction between any two factors $(\mathrm{A} \times \mathrm{B}, \mathrm{A} \times \mathrm{C}$ and $\mathrm{B} \times \mathrm{C})$ did not affect the oil yield in both seasons. 
Table (3): Effect of organic, chemical $\mathrm{N}$ and bio-fertilization on herb dry yield of fennel plants $\left(\mathrm{kg} \mathrm{fed}^{-1}\right)$

\begin{tabular}{|c|c|c|c|c|c|c|c|}
\hline \multirow{3}{*}{$\begin{array}{l}\text { Compost } \\
\text { (A) } t \text { fed }^{-1}\end{array}$} & \multirow{3}{*}{$\begin{array}{l}\text { Chemical } \\
\text { N-fert (B) } \\
\text { Kg N fed }\end{array}$} & \multicolumn{6}{|c|}{ Bio-fertilizer (C) } \\
\hline & & \multicolumn{3}{|c|}{$1^{\text {st }}$ season $(2016 / 2017)$} & \multicolumn{3}{|c|}{$2^{\text {nd }} \operatorname{season}(2017 / 2018)$} \\
\hline & & - & + & Mean & - & + & Mean \\
\hline \multirow{7}{*}{0.0} & 0.0 & 473.2 & 550.2 & 511.7 & 554.4 & 588.1 & 571.3 \\
\hline & 10 urea & 911.4 & 999.6 & 955.5 & 1005.2 & 1020.6 & 1012.9 \\
\hline & $10 \mathrm{AS}$ & 949.2 & 1036.1 & 992.7 & 1022.1 & 1043.1 & 1032.6 \\
\hline & 50 urea & 1145.2 & 1205.4 & 1175.3 & 1206.8 & 1248.8 & 1227.8 \\
\hline & $50 \mathrm{AS}$ & 1170.2 & 1246.0 & 1208.1 & 1226.4 & 1271.2 & 1248.8 \\
\hline & 80 urea & 1324.4 & 1344.0 & 1334.2 & 1352.4 & 1372.1 & 1362.3 \\
\hline & 80 AS & 1339.4 & 1366.6 & 1352.9 & 1401.4 & 1435.0 & 1418.2 \\
\hline \multicolumn{2}{|l|}{ Mean } & 1044.7 & 1106.8 & 1075.8 & 1109.8 & 1139.8 & 1124.8 \\
\hline \multirow{7}{*}{5.0} & $\mathbf{0 . 0}$ & 806.4 & 859.6 & 833.0 & 865.2 & 898.8 & 882.0 \\
\hline & 10 urea & 1261.4 & 1295.1 & 1278.3 & 1300.6 & 1358.1 & 1329.4 \\
\hline & $10 \mathrm{AS}$ & 1292.2 & 1311.8 & 1302.0 & 1323.1 & 1387.4 & 1355.3 \\
\hline & 50 urea & 1377.6 & 1414.0 & 1395.9 & 1432.2 & 1461.6 & 1446.9 \\
\hline & $50 \mathrm{AS}$ & 1395.8 & 1468.6 & 1413.3 & 1450.4 & 1484.1 & 1467.3 \\
\hline & 80 urea & 1411.2 & 1415.4 & 1432.2 & 1456.1 & 1461.6 & 1458.9 \\
\hline & $80 \mathrm{AS}$ & 1444.8 & 1470.1 & 1457.5 & 1481.2 & 1511.8 & 1484.0 \\
\hline \multicolumn{2}{|l|}{ Mean } & 1284.2 & 1319.2 & 1301.7 & 1329.8 & 1366.2 & 1348.0 \\
\hline \multirow{7}{*}{$\begin{array}{l}\text { Mean } \\
\text { Of } \\
\text { N-fert. }\end{array}$} & 0.0 & 639.8 & 704.9 & 672.4 & 709.8 & 743.5 & 726.7 \\
\hline & 10 urea & 1086.4 & 1147.4 & 1116.9 & 1152.9 & 1189.4 & 1171.2 \\
\hline & $10 \mathrm{AS}$ & 1120.7 & 1174.0 & 1147.4 & 1172.6 & 1215.3 & 1194.0 \\
\hline & 50 urea & 1261.4 & 1309.7 & 1285.6 & 1319.5 & 1355.2 & 1337.4 \\
\hline & $50 \mathrm{AS}$ & 1283.0 & 1357.3 & 1320.2 & 1338.4 & 1377.7 & 1358.1 \\
\hline & 80 urea & 1367.8 & 1379.9 & 1373.8 & 1404.3 & 1416.9 & 1410.6 \\
\hline & 80 AS & 1392.1 & 1418.8 & 1405.2 & 1441.3 & 1460.9 & 1451.1 \\
\hline \multicolumn{2}{|c|}{ Mean of BIO- } & 1164.5 & 1213.0 & 1188.8 & 1219.8 & 1258.6 & 1239.3 \\
\hline \multirow{7}{*}{$\begin{array}{l}\text { LSD at } \\
0.05\end{array}$} & $\mathbf{A}$ & & & 15.7 & & & 16.9 \\
\hline & B & & & 13.3 & & & 15.2 \\
\hline & $\mathrm{C}$ & & & 11.5 & & & 12.3 \\
\hline & $\mathbf{A B}$ & & & 11.5 & & & 12.3 \\
\hline & $\mathbf{A C}$ & & & 11.5 & & & 12.5 \\
\hline & BC & & & 11.5 & & & 12.5 \\
\hline & ABC & & & 21.8 & & & 23.1 \\
\hline
\end{tabular}


Table (4): Effect of organic, chemical $\mathrm{N}$ and bio-fertilization on fruit yield of fennel plants $\left(\mathrm{kg} \mathrm{fed}^{-1}\right)$

\begin{tabular}{|c|c|c|c|c|c|c|c|}
\hline \multirow{3}{*}{$\begin{array}{l}\text { Compost (A) } \\
\text { t fed }^{-1}\end{array}$} & \multirow{3}{*}{$\begin{array}{l}\text { Chemical } \\
\text { N-fert (B) } \\
\text { Kg N fed }\end{array}$} & \multicolumn{6}{|c|}{ Bio-fertilizer (C) } \\
\hline & & \multicolumn{3}{|c|}{$1^{\text {st }}$ season $(2016 / 2017)$} & \multicolumn{3}{|c|}{$2^{\text {nd }} \operatorname{season}(2017 / 2018)$} \\
\hline & & - & + & Mean & - & + & Mean \\
\hline \multirow{7}{*}{0.0} & 0.0 & 76.6 & 111.2 & 93.9 & 104.2 & 153.6 & 128.9 \\
\hline & 10 urea & 251.3 & 309.0 & 280.1 & 285.6 & 356.6 & 321.1 \\
\hline & $10 \mathrm{AS}$ & 267.9 & 358.2 & 313.1 & 332.4 & 382.8 & 357.6 \\
\hline & 50 urea & 455.2 & 571.8 & 513.5 & 495.8 & 573.6 & 534.7 \\
\hline & $50 \mathrm{AS}$ & 539.6 & 694.0 & 616.8 & 543.9 & 638.9 & 591.4 \\
\hline & 80 urea & 813.0 & 933.6 & 873.3 & 891.6 & 959.6 & 925.6 \\
\hline & 80 AS & 885.3 & 1000.9 & 943.1 & 963.8 & 1042.5 & 1003.1 \\
\hline Mean & & 469.8 & 568.4 & 519.1 & 516.8 & 586.8 & 551.8 \\
\hline \multirow{7}{*}{5.0} & 0.0 & 166.7 & 237.8 & 202.2 & 226.9 & 277.6 & 252.3 \\
\hline & 10 urea & 502.2 & 643.7 & 572.9 & 595.6 & 706.8 & 651.2 \\
\hline & $10 \mathrm{AS}$ & 531.6 & 676.5 & 604.1 & 639.1 & 758.9 & 599.0 \\
\hline & 50 urea & 823.2 & 1046.9 & 940.1 & 931.0 & 1117.8 & 1024.4 \\
\hline & $50 \mathrm{AS}$ & 890.3 & 1072.7 & 997.5 & 1015.5 & 1218.5 & 1017.2 \\
\hline & 80 urea & 953.6 & 1104.5 & 1013.1 & 1045.2 & 1118.3 & 1082.1 \\
\hline & 80 AS & 1021.2 & 1105.8 & 1063.5 & 1129.1 & 1219.6 & 1174.3 \\
\hline Mean & & 699.8 & 841.1 & 770.5 & 797.5 & 916.8 & 828.6 \\
\hline \multirow{7}{*}{$\begin{array}{l}\text { Mean } \\
\text { Of } \\
\text { N-fert. }\end{array}$} & 0.0 & 121.7 & 174.5 & 148.1 & 164.6 & 190.6 & 190.6 \\
\hline & 10 urea & 376.8 & 476.4 & 426.5 & 440.6 & 531.7 & 486.2 \\
\hline & $10 \mathrm{AS}$ & 399.8 & 517.4 & 458.6 & 485.8 & 570.9 & 478.3 \\
\hline & 50 urea & 644.2 & 809.4 & 726.8 & 713.4 & 845.7 & 779.6 \\
\hline & $50 \mathrm{AS}$ & 715.0 & 899.4 & 807.2 & 779.7 & 928.7 & 804.3 \\
\hline & 80 urea & 849.2 & 1003.1 & 943.2 & 954.5 & 1039.0 & 1003.9 \\
\hline & 80 AS & 953.3 & 1053.4 & 1003.4 & 1046.5 & 1131.1 & 1088.7 \\
\hline Mean of BIO- & & 580.0 & 704.8 & 642.4 & 655.2 & 748.2 & 690.2 \\
\hline \multirow{7}{*}{$\begin{array}{l}\text { LSD at } \\
0.05\end{array}$} & $\mathbf{A}$ & & & 11.3 & & & 13.8 \\
\hline & B & & & 10.1 & & & 11.1 \\
\hline & $\mathbf{C}$ & & & 8.6 & & & 9.7 \\
\hline & $\mathbf{A B}$ & & & 8.6 & & & 9.7 \\
\hline & $\mathrm{AC}$ & & & 8.6 & & & 9.7 \\
\hline & BC & & & 8.6 & & & 9.7 \\
\hline & $\mathbf{A B C}$ & & & 13.7 & & & 16.9 \\
\hline
\end{tabular}


Table (5): Effect of organic, chemical $\mathrm{N}$ and bio-fertilization on essential oil (\%)

\begin{tabular}{|c|c|c|c|c|c|c|c|}
\hline \multirow{3}{*}{$\begin{array}{l}\text { Compost (A) } \\
\text { t fed }^{-1}\end{array}$} & \multirow{3}{*}{$\begin{array}{l}\text { Chemical } \\
\text { N-fert (B) } \\
\text { Kg N fed }^{-1}\end{array}$} & \multicolumn{6}{|c|}{ Bio-fertilizer } \\
\hline & & \multicolumn{3}{|c|}{$1^{\text {st }}$ season } & \multicolumn{3}{|c|}{$2^{\text {nd }}$ season } \\
\hline & & - & + & Mean & - & + & Mean \\
\hline \multirow{7}{*}{0.0} & 0.0 & 1.92 & 1.93 & 1.93 & 1.97 & 1.99 & 1.98 \\
\hline & 10 urea & 1.94 & 1.95 & 1.95 & 2.01 & 2.02 & 2.02 \\
\hline & $10 \mathrm{AS}$ & 1.94 & 1.95 & 1.95 & 2.01 & 2.02 & 2.02 \\
\hline & 50 urea & 1.98 & 2.00 & 1.99 & 2.03 & 2.04 & 2.04 \\
\hline & $50 \mathrm{AS}$ & 1.98 & 2.00 & 1.99 & 2.03 & 2.05 & 2.04 \\
\hline & 80 urea & 2.00 & 2.01 & 2.01 & 2.01 & 2.08 & 2.05 \\
\hline & $80 \mathrm{AS}$ & 2.00 & 2.01 & 2.01 & 2.01 & 2.08 & 2.05 \\
\hline Mean & & & 1.98 & 1.98 & 2.01 & 2.04 & 2.03 \\
\hline \multirow{7}{*}{5.0} & 0.0 & 1.95 & 1.96 & 1.96 & 2.01 & 2.03 & 2.02 \\
\hline & 10 urea & 1.97 & 1.99 & 1.98 & 2.03 & 2.06 & 2.04 \\
\hline & $10 \mathrm{AS}$ & 1.97 & 1.98 & 1.98 & 2.04 & 2.08 & 2.06 \\
\hline & 50 urea & 2.00 & 2.01 & 2.01 & 2.05 & 2.11 & 2.08 \\
\hline & $50 \mathrm{AS}$ & 2.00 & 2.01 & 2.01 & 2.06 & 2.11 & 2.09 \\
\hline & 80 urea & 2.03 & 2.04 & 2.04 & 2.08 & 2.15 & 2.12 \\
\hline & $80 \mathrm{AS}$ & 2.03 & 2.04 & 2.04 & 2.08 & 2.15 & 2.12 \\
\hline \multicolumn{2}{|l|}{ Mean } & & 2.00 & 2.00 & 2.05 & 2.10 & 208 \\
\hline \multirow{7}{*}{$\begin{array}{l}\text { Mean } \\
\text { Of } \\
\text { N-fert. }\end{array}$} & 0.0 & 1.94 & 1.95 & 1.95 & 1.99 & 2.01 & 2.00 \\
\hline & 10 urea & 1.96 & 1.97 & 1.97 & 2.02 & 2.04 & 2.03 \\
\hline & $10 \mathrm{AS}$ & 1.96 & 1.97 & 1.97 & 2.03 & 2.05 & 2.04 \\
\hline & 50 urea & 1.99 & 2.01 & 2.00 & 2.04 & 2.08 & 2.06 \\
\hline & $50 \mathrm{AS}$ & 1.99 & 2.01 & 2.00 & 2.05 & 2.08 & 2.07 \\
\hline & 80 urea & 2.02 & 2.03 & 2.03 & 2.05 & 2.12 & 2.09 \\
\hline & $80 \mathrm{AS}$ & 2.02 & 2.03 & 2.03 & 2.05 & 2.12 & 2.09 \\
\hline \multicolumn{2}{|l|}{ Mean of BIO- } & & 2.00 & 1.99 & 2.03 & 2.07 & 2.05 \\
\hline \multirow{7}{*}{$\begin{array}{l}\text { LSD at } \\
0.05\end{array}$} & $\mathbf{A}$ & & & 0.01 & & & 0.02 \\
\hline & B & & & 0.01 & & & 0.01 \\
\hline & C & & & 0.01 & & & 0.01 \\
\hline & $\mathbf{A B}$ & & & N.S & & & N.S \\
\hline & $\mathbf{A C}$ & & & N.S & & & N.S \\
\hline & BC & & & N.S & & & N.S \\
\hline & $\mathbf{A B C}$ & & & N.S & & & N.S \\
\hline
\end{tabular}


Table (6): Effect of organic, chemical $\mathrm{N}$ and bio-fertilization on essential oil yield ( $\left.\mathrm{L} \mathrm{fed}^{-1}\right)$ in fennel fruits

\begin{tabular}{|c|c|c|c|c|c|c|c|}
\hline \multirow{3}{*}{$\begin{array}{l}\text { Compost } \\
\text { (A) } \\
\text { f fed }^{-1}\end{array}$} & \multirow{3}{*}{$\begin{array}{l}\text { Chemical } \\
\text { N-fert (B) } \\
\text { Kg N fed }^{-1}\end{array}$} & \multicolumn{6}{|c|}{ Bio-fertilizer (C) } \\
\hline & & \multicolumn{3}{|c|}{$1^{\text {st }}$ season $(2016 / 2017)$} & \multicolumn{3}{|c|}{$2^{\text {nd }} \operatorname{season}(2017 / 2018)$} \\
\hline & & - & + & Mean & - & + & Mean \\
\hline \multirow{7}{*}{0.0} & 0.0 & 1.470 & 2.146 & 1.803 & 2.053 & 3.057 & 2.552 \\
\hline & 10 urea & 4.875 & 6.026 & 5.434 & 5.741 & 7.203 & 6.454 \\
\hline & $10 \mathrm{AS}$ & 5.197 & 6.985 & 6.073 & 6.681 & 7.733 & 7.188 \\
\hline & 50 urea & 9.013 & 11.436 & 10.219 & 10.064 & 11.701 & 10.854 \\
\hline & $50 \mathrm{AS}$ & 10.684 & 13.880 & 12.274 & 11.041 & 13.097 & 12.065 \\
\hline & 80 urea & 16.260 & 18.765 & 17.510 & 18.367 & 19.960 & 19.160 \\
\hline & $80 \mathrm{AS}$ & 17.706 & 20.118 & 18.909 & 19.854 & 21.684 & 20.764 \\
\hline Mean & & 9.315 & 11.337 & 10.326 & 10.548 & 12.063 & 11.290 \\
\hline \multirow{7}{*}{5.0} & 0.0 & 3.251 & 4.661 & 3.943 & 4.561 & 5.635 & 5.095 \\
\hline & 10 urea & 9.893 & 12.810 & 11.343 & 12.091 & 14.560 & 13.284 \\
\hline & $10 \mathrm{AS}$ & 10.473 & 13.395 & 11.900 & 13.038 & 15.785 & 12.339 \\
\hline & 50 urea & 16.664 & 21.043 & 18.801 & 19.086 & 23.586 & 21.308 \\
\hline & 50 AS & 17.806 & 22.204 & 19.951 & 20.919 & 24.043 & 21.209 \\
\hline & 80 urea & 19.358 & 21.879 & 20.565 & 21.740 & 25.710 & 22.832 \\
\hline & $80 \mathrm{AS}$ & 20.730 & 22.558 & 21.590 & 23.485 & 26.221 & 24.778 \\
\hline Mean & & 14.025 & 16.936 & 15.442 & 16.417 & 19.363 & 17.890 \\
\hline \multirow{7}{*}{$\begin{array}{l}\text { Mean } \\
\text { Of } \\
\text { N-fert. }\end{array}$} & 0.0 & 2.361 & 3.403 & 2.873 & 3.411 & 3.831 & 3.812 \\
\hline & 10 urea & 7.385 & 9.385 & 8.359 & 8.900 & 10.847 & 9.870 \\
\hline & $10 \mathrm{AS}$ & 7.836 & 10.193 & 8.989 & 9.861 & 11.703 & 9.757 \\
\hline & 50 urea & 12.820 & 16.268 & 14.536 & 14.553 & 17.591 & 16.060 \\
\hline & $50 \mathrm{AS}$ & 14.229 & 18.077 & 16.144 & 15.984 & 19.317 & 16.569 \\
\hline & 80 urea & 17.154 & 20.362 & 18.788 & 19.758 & 22.027 & 20.982 \\
\hline & 80 AS & 19.257 & 21.383 & 19.155 & 21.663 & 23.979 & 22.754 \\
\hline \multicolumn{2}{|l|}{ Mean of BIO- } & 11.577 & 14.153 & 12.730 & 13.447 & 15.614 & 14.258 \\
\hline \multirow{7}{*}{$\begin{array}{l}\text { LSD at } \\
0.05\end{array}$} & $\mathbf{A}$ & & & 1.91 & & & 2.13 \\
\hline & B & & & 1.03 & & & 1.25 \\
\hline & $\mathbf{C}$ & & & 1.01 & & & 1.17 \\
\hline & $\mathbf{A B}$ & & & N.S & & & N.S \\
\hline & $\mathbf{A C}$ & & & N.S & & & N.S \\
\hline & BC & & & N.S & & & N.S \\
\hline & $\mathbf{A B C}$ & & & 3.56 & & & 3.81 \\
\hline
\end{tabular}


On the other hand, the three-way interaction (A x $\mathrm{B} \times \mathrm{C}$ ) had significant effect on oil yield during the two growing seasons. In general, the highest oil yield (22.558 and $26.221 \mathrm{~L} \mathrm{fed}^{-1}$ in both seasons, respectively) were recorded for the fennel plants supplied with $5 \mathrm{t}$ compost $\mathrm{fed}^{-1}+80 \mathrm{~kg} \mathrm{~N}^{-1} \mathrm{fed}^{-1}$ as ammonium sulphate + bio-fertilizer. The lowest oil yield (1.470 and $2.053 \mathrm{~L}$ $\mathrm{fed}^{-1}$ in the two seasons, respectively) were achieved for the untreated plants (control).

\section{DISCUSSION}

Based on the obtained results, herb, fruit and oil yields of the fennel plants were exhibited highly responsiveness to $\mathrm{ng}$ effect of compost on the fennel yields and oil content might be due the role of compost in improving soil structure and root development, supplying nutrients and enhancing the nutrients absorption (Hussein et al., 2006; Younesian et al., 2013; and Abd El-Aleem et al., 2017).

It is clear from the obtained results that increasing nitrogen level enhanced herb and fruit yields as well as oil percentage and yield due to the role of $\mathrm{N}$ in increasing cell division and elongation (Bharaguva, 1991). In this respect, Dordas and Sioulas (2008) reported that nitrogen could affect organs development and seed formation by increasing metabolites, photosynthesis, dry matter weight and the amount of plant assimilates. Moreover, the enough nitrogen application increased oil percentage and yield due to enhancing photosynthesis rate, the rapidly of plant growth and to the production of suitable biomass and basic metabolism, which resulted in directly or indirectly increases in production and accumulation of primary and secondary metabolites. These results are in the same line with those obtained by Sifola and Barbieri (2006), Tanious (2008) and Ayyat (2017).

The obtained data showed that herb, fruit and oil yields, were significantly responded to nitrogen source. In both seasons' ammonium sulphate exceeded urea fertilizer. The superiority of ammonium sulphate over urea might be due to its more acidic effect on soil reaction than urea (Fageria et al., 2010), accordingly modified soil $\mathrm{pH}$ near roots and in turn increased the availability of nutrients. These results are agreed with those obtained by Osman et al. (2001) and Ismail et al. (2006).

Herb and fruit yields as well as oil yield were significantly responded to the added bio- fertilizer. These increments could be ascribed to the positive effect of bio-fertilizer on enhancing the assimilation processes of plants. Similar finding was reported by $\mathrm{Wu}$ et al. (2005) who indicated that the beneficial effects of bio-fertilizer might be attributed to their enhancing for $\mathrm{N}$-fixing activities and promoting growth substances like gibberellins, indole acetic acid and cytokinine substances. Moreover, Abd El-Aziz et al. (2007) reported that the promoting effect of bio-fertilizer on fennel yield and oil might be due to its positive effect on growth parameters and chemical composition of plant such as N, P, K and total carbohydrates, which affected herb and fruit yields, and oil percent and yield. These results are in harmony with those obtained by Darzi (2012) and Younesian (2013).

Regarding the interaction effect of the studied treatments, fruit and oil yields were significantly affected by the three-way interaction among compost, nitrogen and bio-fertilizers. Fruit and oil yields resulted from the combined of $50 \mathrm{~kg} \mathrm{~N}$ fed ${ }^{-1}$ with $5 \mathrm{t} \mathrm{fed}^{-1}$ compost and bio-fertilizer were statistically equal to those obtained by added $80 \mathrm{~kg} \quad \mathrm{~N}$ fed $^{-1}$. The enhancement effects of the applied nitrogen fertilizer on fruit and oil yields in the presence of organic and biofertilizers were achieved by many authors like Salim and Awad (2005), Mahfouz and Sharaf-Eldin (2007), Dodkhan (2012) and Ayyat (2017).

\section{CONCLUSION}

The results of this study indicated that we can

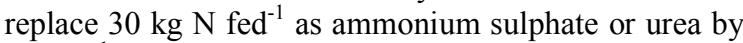
$5 \mathrm{t} \mathrm{fed}^{-1}$ compost and bio-fertilization to maximize herb and fruit yields and oil yield of fennel plant.

\section{REFERENCES}

AOAC (1985). Association of Official Agricultural Chemists. Official Methods of Analysis. A.O.A.C. Benjamin Fraklin Station Washington, D.C. M.S.A., PP. 440-512.

Abd El-Aleem, W, S. F. Henday, E. S. Hamed and W. I. M. Toaima (2017). Effect of planting dates, organic fertilization and foliar spray of algae extract on productivity of Dutch fennel plant under Sinai conditions. J. Med. Plants Stud., 5: 377-334.

Abd El-Aziz, M., R. Pokluda and M. Abd-El-Wahab (2007). Influence of compost, microorganisms and NPK fertilizer upon growth, chemical composition and essential oil production of Rosmarinus offcinals L. Not. Bot. Hort. Agrobot. Cluj., 35: 86-90.

Ayyat, A. M. M. (2017). Response of fennel (Foeniculum vulgare Mill.) plants to mineral, organic and bio-fertilization, as well as royal jelly treatments. Ph.D. Thesis, Fac., of Agric., Minia Univ. Egypt.

Bharaguva, P. L. (1991). Proceedings of International Workshop on Orobanche Research. Obemarchatal, FRG.

Charles, D. J., M. R. Morals and J. E. Simon (1993). Essential oil content and chemical composition of finocchio fennel. In: Janick, J. and J. E. Simon (eds), New Crops. Willey New York, pp 570-573.

Chiej, R. (1984). The Macdonald Encyclopedia of Medicinal Plants. Macdonald and Co., London.

Darzi, M. T. (2012). Effect of biofertilizers application on quantitative and qualitative yield of fennel (Foeniculum vulgare) in a sustainable production system. Int. J. Agric. Crop Sci., 4: 187-192. 
Dodkhan, L. (2012). Effect of chemical and biofertilizers on yield, growth parameters and essential oil contents of fennel (Foeniculum vulgare Miller). J. Medic. Plants and Byproducts, 2: 101-105.

Dordas, C. A. and C. Sioulas (2008). Safflower yield, chlorophyll content, photosynthesis and water use efficiency response to nitrogen fertilization under rain fed conditions. Ind. Crop. Prod. 27: 75-85.

El-Wahab, A. and A. Mohamed (2007). Effect of nitrogen and magnesium fertilization on the production of Tracysper mumammi L. (Agowan) plants under Sinai conditions. J. App. Sci. Res., 3: 781-786.

Fageria, N. K., A. B. Dossantos and M. F. Moraes (2010). Influence of urea and ammonium sulfate on soil acidity indices in lowland rice production. Commun. Soil Sci. Plant Anal., 41: 1565-1575.

Hussein, M. S., S. E. El-Sherbeny, M. Y. Khalil and S. M. Aly (2006). Growth characters and chemical constituents of Dracocephalum moldavica L. plants in relation to compost fertilizer and planting distance. Sci. Hortic., 108: 322-331.

Ismail, S. A., M. A. Morsy, A. A. Omran and M. M. Foaad (2006). The productivity, of some hybirds (Zea mays L.) grown in an alluvial soil under different nitrogen sources and levels. The Second Conference of Farm Integrated Pest Management. Faculty of Agric., Fayoum Univ. Egypt, 16-18 January.

Klute, A. (1986). Methods of Analysis. Part-1: Physical and Mineralogical Methods $\left(2^{\text {nd }}\right.$ ed). Amer. Soci., Agron., Madison, Wisconsin, USA.

Mahfouz, S. A. and M. A. Sharaf-Eldin (2007). Effect of mineral vs. biofertilizer on growth, yield, and essential oil content of fennel
(Foeniculum vulgare Mill). Int. Agropysics, 21: 361-366.

Metin, T. A., G. B. Medine, C. C. Ramazan, O. F. Taskin and D. Sahin (2010). The effect of PGPR strain on wheat yield and quality parameters. Proc. of World Congress of Soil Sci., Soil Solutions for Changing World 1-6 August, Brisbane, Australia.

Osman, A. S., S. M. M. Allam, G. M. EL-Shebang and M. Y. Gebraiel (2001). Influence of nitrogen and micronutrient sources on maije plants. Egypt J. Appl. Sci., 16(4): 150-160.

Salim, A. G. and A. M. Awad (2005). Response of coriander plants to organic and mineral fertilizers in sandy soils. Egypt. J. Agric. Res., 83(2): 829-858.

Sifola, M. I. and G. Barbieri (2006). Growth yield and essential oil content of three cultivars of basil growth under level of nitrogen in the field. Sci. Hortic., 108: 408-413.

Snedecor, G. W. and W. G. Cochran (1980). Statistical Methods. $7^{\text {th }}$ Ed., Amers, Iowa State Unive. Press, Iowa, USA.

Tanious, C. T. (2008). Effect of some organic and biofertilization treatment on fennel plants. M.Sc. Thesis, Fac., of Agric. Minia Univ., Egypt.

Tisdale, S. L. and W. L. Nelson (1975). Soil Fertility and Fertilizer. The Macmillan Company, New York.

Wu, S. C., Z. H. Cao, Z. G. Li and K. C. Chung (2005). Effect of boifertilizer containing N2-fixer, $\mathrm{P}$ and $\mathrm{K}$ solubilizers and $\mathrm{A}$. $\mathrm{M}$. fungi on maize growth: A greenhouse trail. Geoderma, 125: 155-166.

Younesian, A., S. Taheri and P. R. Moghaddam (2013). The effect of organic and biological fertilizers on essential oil content of foeniculum vulgare Mill. (Sweet Fennel). Int. J Agri. Crop Sci., 5: 2141-2146.

\footnotetext{
تأثير مصادر ومستويات مختلفة من الأسمدة النيتروجينية المعدنية في وجود التسميد العضوي

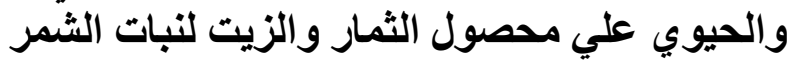

أجريت تجربتان حقليتان في أرض آن حديثة الاستصلاح بمزرعة خاصة بالقرية الثامنة بمحافظة المنيا ـ خلال موسمي نمو متتالين

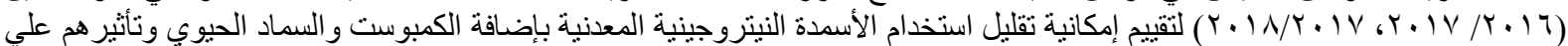

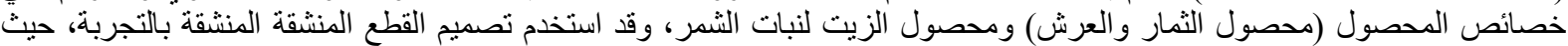

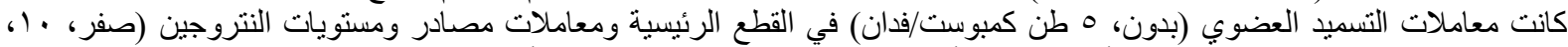

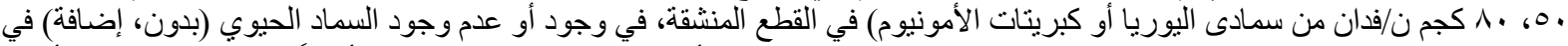

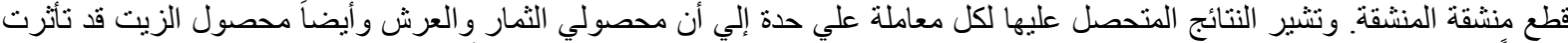

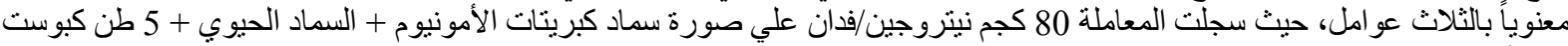
فدان أعلي القيم.
} 